Jurnal MAKSIPRENEUR, Vol. I, No. 1, 2011, hal. 108-119

\title{
PERSEPSI REMAJA TERHADAP PENYULUHAN KESEHATAN REPRODUKSI REMAJA DI KECAMATAN WIROBRAJAN YOGYAKARTA
}

\author{
Nur Budyantara \& Jemadi \\ Fakultas Ekonomi Universitas Proklamasi 45, Yogyakarta
}

ABSTRACT. The research on adolescence perception to their reproduction health guidance in Wirobrajan District, Yogyakarta could give an illustration on a very well, well or poor perception guidance variables. Adolescence reproduction health guiding function was to guide and to direct adolescence in order to avoid from a disadvantageous behaviour for their future lives such as free association, pre-marriage sexual intercourse, sexual affected disease, drugs abuse, drinking, criminal acts and soon. Adolescence reproduction health program was conducted through several approaches were among others: Firstly, family communication approach i.e. a program given through interpersonal communication between parents and their adolescence phase and learning/ teaching approach, aimed to give adolescence reproduction health program in school through intra-curricular and extra-curricular. Secondly, a counselling approach meant that given to the adolescence and their parents in a school guidance activity form as well as society through social group/ organization such as youth workshop, Family Wellness Program (PKK), BKR, and soon.

From the research result, it was known that adolescence perception to reproduction health guidance was averagely good, except its perception credibility was very good, adolescence concept or ways most liked on adolescence health guidance was conducted a direct guidance using demonstration tools. Viewed from an adolescence perception difference on adolescence reproduction health guidance was based on sex, age, origin, school, parent educational level and occupation. From the analysis result, there was no respondent perception difference viewed from sex, age, origin, school, parent educational level and occupation.

Keywords: Adolescence perception, guidance, reproduction health guidance 


\section{PENDAHULUAN}

Dalam masyarakat maju dan modern, kedudukan, fungsi dan peranan keluarga semakin longgar sehingga fungsi keluarga untuk mendidik dan membina anak kadang kala kurang mendapat perhatian dengan sungguhsungguh. Masa remaja adalah masa labil bagi anak, keingintahuan akan hal baru sangatlah tinggi. Untuk menghindari terjadinya salah arah mengenai kesehatan reproduksi maka remaja perlu dibekali mengenai kesehatan reproduksi

Pengertian kesehatan reproduksi yang telah disepakati dalam konferensi Internasional Kependudukan dan Pembangunan (ICPD) di Kairo tahun 1994 adalah keadaan kesehatan yang sempurna baik secara fisik, mental dan sosial dan bukan semata-mata terbebas dari penyakit atau kecacatan dalam segala aspek yang berhubungan dengan sistem reproduksi dan fungsi-fungsi serta proses-prosesnya (BKKBN, 2000:7).

Tujuan kesehatan reproduksi remaja adalah agar remaja dan orang tuanya memiliki pengatahuan, sikap dan perilaku reproduksi sehat untuk mewujudkan ketahanan keluarga menuju keluarga sejahtera. Fungsi kesehatan reproduksi remaja adalah membina dan mengarahkan generasi muda agar dapat terhindar dari perilaku yang merugikan masa depan kehidupannya seperti pergaulan bebas, hubungan seks pra nikah, penyakit menular seksual, penyalahgunaan obat terlarang, minum-minuman keras, tindak kriminal dan lain-lain.

Program kesehatan reproduksi remaja dilaksanakan melalui beberapa pendekatan antara lain:

1. Pendekatan komunikasi dalam keluarga, yaitu program yang diberikan melalui komunikasi interpersonal antara orang tua dengan putraputrinya yang telah menginjak masa remaja.

2. Pendekatan pendidikan / pengajaran, dimaksudkan pemberian program kesehatan reproduksi remaja di sekolah melalui kegiatan intra dan ekstra kurikuler.

3. Pendekatan konseling, artinya yang diberikan kepada remaja dan orang tuanya dalam bentuk kegiatan penyuluhan di sekolah maupun masyarakat melalui kelompok/organisasi sosial seperti karang taruna, PKK, BKR dan lain-lain (BKKBN, 200o)

Untuk memantapkan keberhasilan Program BKKBN dalam pemberdayaan terhadap Remaja melalui Kesehatan Reproduksi Remaja, maka perlu diteliti tentang persepsi terhadap penyuluhan Kesehatan Reproduksi Remaja yang dilaksanakan di Kecamatan Wirobrajan Yogyakarta. 


\section{PERUMUSAN MASALAH}

Rumusan masalah dalam penelitian ini adalah:

1. Bagaimana persepsi remaja terhadap penyuluhan Kesehatan Reproduksi Remaja di Kecamatan Wirobrajan Yogyakarta?

2. Konsep apa yang paling disukai remaja pada saat penyuluhan Kesehatan Reproduksi Remaja?

3. Apakah ada perbedaan persepsi remaja terhadap penyuluhan Kesehatan Reproduksi Remaja yang dilakukan oleh BKKBN Propinsi DIY berdasarkan jenis kelamin, umur, pendidikan, asal daerah, pendidikan orang tua dan pekerjaan orang tua?

\section{TINJAUAN PUSTAKA}

Pengertian Remaja adalah masa peralihan dari anak, menjadi orang dewasa secara fisik, mental dan sosial. Masa remaja umumnya berkisar antara 11 - 21 tahun yang terdiri dari usia 11 - 13 tahun yang dikenal dengan masa remaja awal atau pubertas, kemudian usia $14-18$ atau remaja dan usia 19 - 21 tahun atau masa Pemuda (BKKBN, 2000).

Persepsi adalah proses dimana konsumen menyadari dan penginterprestasikan aspek lingkungannya atau dapat dikatakan sebagai proses penerimaan dan adanya rangasangan di dalam lingkungan intern dan ekstern, sehingga persepsi bersifat aktif (Swastha dan T.Hani Handoko,200o). Selanjutnya proses persepsi secara sederhana dapat digambarkan sebagai berikut:

\section{Proses Persepsi yang Sederhana}

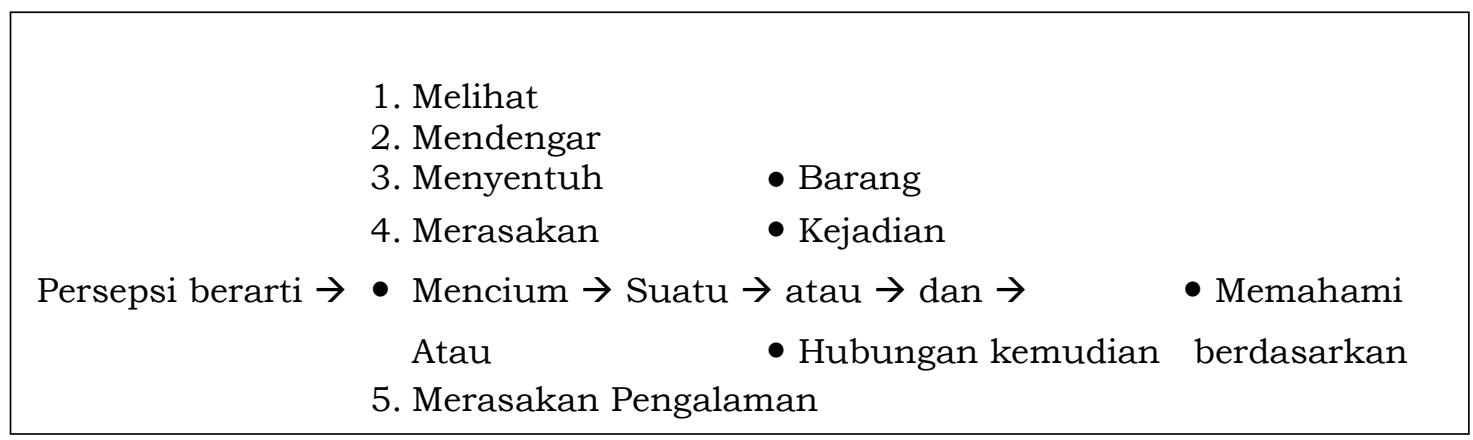

Penyuluhan Kesehatan Reproduksi Remaja adalah merupakaan suatu jasa, Parasuraman, Zeithaml, dan Berry yang dikutip oleh (Fandy Tjiptono, 2001) berhasil mengidentifikasi 10 atribut yang menentukan kualitas jasa. Kesepuluh atribut tersebut meliputi: Reliability, Responsiveness, Competence, Access, Communication, Credibility, Security, Understanding/ knowing the customer, dan Tangible. 
Karakteristik respondden dalam penelitian ini adalah berdasarkan: jenis kelamin, umur, daerah asal, asal sekolah, pendidikan orang tua, pekerjaan orang tua, sehingga dapat dibuat skema kerangkan pikir seperti dibawah ini.

\section{Persepsi Responden terhadap Atibusi Jasa}

\begin{tabular}{|ll|}
\hline & $\begin{array}{c}\text { Responden } \\
\text { (Remaja) }\end{array}$ \\
\hline 1. Jenis kelamin \\
2. Umur \\
3. Daerah Asal \\
4. Asal sekolah \\
5. Pendidikan orangtua \\
6. Pekerjaan orang tua
\end{tabular}

\begin{tabular}{|ll|}
\hline & \multicolumn{1}{c|}{ Jasa } \\
& (Penyuluhan KRR) \\
\hline 1. & \multicolumn{1}{c|}{ Atribut: } \\
2. & Responsiveness \\
3. & Competence \\
4. & Acces \\
5. & courtesy \\
6. & comunication \\
7. & credibility \\
8. & security \\
9. & knowing the Undestanding \\
10. Customer Tangible
\end{tabular}

\section{TUJUAN DAN MANFAAT PENELITIAN}

Tujuan penelitian ini adalah sebagai berikut:

1. Untuk mengetahui persepsi remaja terhadap penyuluhan kesehatan reproduksi remaja

2. Untuk mengetahui konsep yang paling disukai remaja tentang penyuluhan kesehatan reproduksi remaja

3. Untuk mengetahui perbedaan persepsi remaja tetang penyuluhan kesehatan reproduksi remaja, berdasarkan jenis kelamin, umur,asal daerah ,asal sekolah, tingkat pendidikan orang tua, serta pekerjaan orang tua.

\section{METODE PENELITIAN}

Dalam penelitian ini ada dua jenis variabel yaitu variabel independen dan dependen. Sebagai variabel independen dalam penelitian ini adalah karakteristik jenis kelamin, umur, asal daerah, asal sekolah, pendidikan orang tua, dan pekerjaan orang tua. Sedangkan variabel dependen adalah persepsi remaja. Persepsi remaja terhadap penyuluhan kesehatan reproduksi remaja yang meliputi: kemampuan konselor atau tenaga ahli dalam penyuluhan, kesiapan konselor, sejauh mana tingkat profesionalisme para konselor, hubungan remaja terhadap para konselor pada saat 
memberikan penyuluhan, menyampaikan materi, bagaimana komunikasi yang baik para konselor, diskusi terbuka dan jujur, bagaimana suasana dalam penyuluhan apakah sudah terbentuk suasana yang nyaman, aman tanpa keraguan, pemenuhan kriteria tentang bagaimana pemahaman materi yang dibutuhkan saat memberikan penyuluhan, dan dalam penyuluhan telah menggunakan peragaan ataupun gambar sehingga dapat memperjelas dalam kegiatan penyuluhan tersebut.

Atribut dalam komponen yang merupakan sifat dari jasa dan melekat pada penyuluhan kesehatan reproduksi remaja yang akan diteliti adalah sebagai berikut:

1. Reliability adalah bahwa kemampuan konselor atau tenaga ahli seperti dokter dalam memberikan penyuluhan sudah baik.

2. Responsiveness berarti kesiapan konselor dalam memberikan penyuluhan.

3. Competence berarti tingkat profesionalisme para penyuluh tidak diragukan lagi.

4. Acces artinya hubungan remaja terhadap para penyuluh sudah terjalin baik dan akrab.

5. courtesy berarti penyampaian materi penyuluhan mudah difahami oleh para remaja.

6. comunication berarti sudah terjalin komunikasi yang baik antara remaja penyuluh pada saat penyuluhan

7. credibility adalah berarti dalam penyuluhan para konselor sudah terjalin diskusi terbuka dan jujur kepada para remaja.

8. security berarti di dalam penyuluhan telah terbentuk suasana yang nyaman, aman, dan tanpa keragu-raguan.

9. knowing the Undestanding/knowing the customer yang artinya para penyuluhan telah menggunakan sarana peragaan gambar atau sarana yang lain yang dapat memperjelas kegiatan penyuluhan tersebut.

10. Customer Tangible artinya dalam pelaksanaan penyuluhan telah menggunakan sarana peragaan gambar atau sarana yang lain yang dapat memperjelas kegiatan penyuluhan tersebut.

Karakteristik Remaja, dilihat dari: Jenis kelamin (laki-laki, perempuan). Asal daerah (dalam kecamatan Wirobrajan, Luar Kecamatan Wirobrajan, Luar Kota Yogyakarta) ,Umur ( $\leq 17$ tahun, 18 - 20 tahun, $\geq 21$ tahun), Asal Sekolah (SMA, SMK), Pendidikan orang tua (SD, SMP, SMA, Perguruan Tinggi), Pekerjaan orang tua (Petani, swasta, PNS, Wiraswasta, ABRI/POLRI)

Populasi dan Sampel, Populasi dalam perhatian ini adalah semua remaja di Kecamatan Wirobrajan Yogyakarta, sedangkan sampelnya 
sebanyak 140 remaja yang yang diambil secara accidental sampling (Sugiyono, 1999)

Metode pengumpulan data, pengumpulan data menggunakan koesioner, dengan alternatif jawaban: Sangat setuju 5, Setuju 4, Ragu-ragu 3, Tidak setuju 2, Sangat tidak setuju 1

Analisis yang digunakan adalah Analisis kualitatif dan kuantitatif dengan Analisis rata-rata hitung, Uji perbedaan rata-rata t test, digunakan untuk menguji perbedaan persepsi responden menurut karakteristiknya (Jenis kelamin dan asal sekolah). Uji perbedaan rata-rata F test, digunakan untuk menguji perbedaan persepi responden menurut karakteristiknya (jenis kelamin, umur, asal daerah, asal sekolah, pendidikan orang tua, pekerjaan orang tua (Jarwanto dan Pangestu Subagyo, 1997)

\section{HASIL DAN PEMBAHASAN}

Hasil Analisis kuntitatif karakteristik responden: berdasarkan jenis kelamin jumlah responden perempuan sebanyak 137 orang atau 98,oo \% dan responden laki-laki sebanyak 3 orang atau sebesar 2,0o \%, Karakteristik Responden berdasarkan usia responden dengan umur lebih kecil 18 tahun sebanyak 10 orang atau 7,00 \%, responden dengan umur antara 18 tahun sampai dengan 20 tahun sebanyak 124 orang atau 89,00\%, sedangkan responden dengan umur lebih dari i 23 tahun sebanyak 6 orang atau 64,00\%. Karakteristik Responden berdasarkan Daerah Asal, responden yang berasal dari dalam Kecamatan Wirobrajan sebanyak 77 responden atau 55,00 \%, dari luar Kecamatan Wirobrajan tetapi masih dalam Kota Yogyakarta sebanyak 41 responden atau 29,0o \% sedang yang berasal dari luar kota Yogyakarta sebanyak 22 responden atau 16,0o \%. Karakteristik Responden Berdasarkan Asal Sekolah, responden dengan asal sekolag di SMA sebanyak 119 orang atau 85,0o \%, sedang yang berasal dari SMK sebanyak 21 orang atau 15,00 \%. Karakteristik responden berdasarkan pendidikan orang tua responden adalah perguruan tinggi yaitu sebanyak 78 orang atau $56 \%$, orang tua responden berpendidikan SLTA sebanyak 33 orang atau $24 \%$, sedang orang tua responden yang berpendidikan SMP sebanyak 21 orang atau $14 \%$, serta yang berpendidikan SD hanya sebanyak 8 atau $6 \%$ saja. Karakretistik responden berdasarkan pekerjaan orang tua pekerjaan orang tua responden sebagai petani sebanyak 7 responden atau 5 $\%$ hal ini di karenakan di wilayah Kecamatan Wirobrajan memang lahan pertananian sudah hampir habis dan pekerjaan terbesar sebagai PNS yaitu sebanyak 58 responden atau $41 \%$

Analisis Kuantitatif, dengan Analisis rata-rata hitung, Analisis ini digunakan untuk mengetahui tanggapan responden secara kseluruhan berdasarkan atribut tanpa membedakan karakteristik dengan penilaian sebagai berikut: skor 1,oo $-1,79=$ Sangat Tidak Baik ; skor 1,80 - 2,59= 
Tidak Baik; skor 2,6o - 3,39= Cukup Baik; skor 3,40 - 4,19= Baik ; skor 4,20 $-5,00=$ Sangat Baik .

Secara keseluruhan tanggapan responden sebagaimana tersebut dalam tabel berikut ini:

Tanggapan Responden atas Atribut Penelitian

\begin{tabular}{|c|c|c|c|c|c|c|c|c|c|}
\hline \multirow[b]{3}{*}{ No } & \multirow[b]{3}{*}{ Atribut } & \multicolumn{5}{|c|}{ Tanggapan } & \multirow{2}{*}{\multicolumn{2}{|c|}{ Jumlah }} & \multirow{3}{*}{$\begin{array}{l}\text { Rata- } \\
\text { rata }\end{array}$} \\
\hline & & \multirow{2}{*}{$\frac{\text { SS }}{5}$} & \multirow{2}{*}{$\begin{array}{l}S \\
4\end{array}$} & \multirow[t]{2}{*}{$\mathbf{R}$} & \multirow{2}{*}{$\frac{\text { TS }}{2}$} & \multirow{2}{*}{$\frac{\text { STS }}{1}$} & & & \\
\hline & & & & & & & $\begin{array}{c}\text { Respo } \\
\text { nden }\end{array}$ & Skor & \\
\hline 1 & Responsiveness & 28 & 102 & 9 & o & 1 & 140 & 576 & 4,11 \\
\hline 2 & Reliability & 16 & 99 & 25 & o & o & 140 & 551 & 3,93 \\
\hline 3 & Competence & 17 & 109 & 14 & o & $\mathrm{o}$ & 140 & 563 & 4,02 \\
\hline 4 & Access & 9 & 72 & 57 & 2 & o & 140 & 508 & 3,63 \\
\hline 5 & Courtesy & 24 & 94 & 22 & o & o & 140 & 562 & 4,01 \\
\hline 6 & Comunication & 12 & 89 & 39 & o & o & 140 & 533 & 3,80 \\
\hline 7 & Credibility & 50 & 72 & 18 & o & o & 140 & 592 & 4,23 \\
\hline 8 & Security & 21 & 85 & 33 & 1 & o & 140 & 546 & 3,90 \\
\hline 9 & $\begin{array}{l}\text { Knowing the } \\
\text { Understanding }\end{array}$ & 12 & 109 & 19 & o & o & 140 & 553 & 3,95 \\
\hline 10 & Customer Tangible & 37 & 77 & 24 & 2 & o & 140 & 569 & 4,06 \\
\hline & Jumlah & 226 & 908 & 260 & 5 & 1 & 1400 & 5553 & 39,64 \\
\hline & Rata-rata & 22,6 & 90,8 & 26 & 0,5 & 0,1 & 140 & 55,53 & 3,96 \\
\hline
\end{tabular}

Berdasarkan tabel tersebut diatas diperoleh hasil rata-rata hitung dari persepsi responden sebesar 3,96 dan termasuk dalam kategori baik karena berada di antara skor 3,40 - 4,19. Sedangkan jika dilihat dari setiap atribut adalah sebagai berikut

1. Responsiveness. Sebagian besar responden menyatakan setuju terhadap aspek responsiveness, berupa kemampuan tenaga penyuluh dalam memberikan penyuluhan kesehatan reproduksi dengan nilai 576 atau rata-rata sebesar 4,11 yang terletak diantara 3,4 - 4,19 sehingga termasuk katergori baik.

2. Realibility, Responden menyatakan setuju terhadap aspek reliability, berupa kesiapan tenaga penyuluh dalam memberikan penyuluhan kesehatan reproduksi dengan nilai 551 atau rata-rata sebesar 3,93 sehingga termasuk katergori baik karena berada diantara skor 3,4 - 4,19.

3. Competence, Responden menyatakan setuju terhadap aspek competence, berupa cara kerja tenaga penyuluh dalam memberikan penyuluhan kesehatan Reproduksi dengan nilai 563 atau rata-rata sebesar 4,02 sehingga termasuk katergori baik karena berada diantara skor 3,4-4,19. 
4. Access, Responden menyatakan setuju terhadap aspek access, berupa hubungan yang baik antara tenaga penyuluh dengan responden dalam memberikan penyuluhan kesehatan reproduksi dengan nilai 508 atau rata-rata sebesar 3,63 sehingga termasuk katergori baik karena berada diantara skor 3,4-4,19.

5. Courtesy, Responden menyatakan setuju terhadap aspek courtesy , berupa penyampaian materi oleh tenaga penyuluh sudah baik dan mengena sasaran dengan responden dalam memberikan penyuluhan kesehatan reproduksi dengan nilai 562 atau rata-rata sebesar 4,01 sehingga termasuk katergori baik karena berada diantara skor 3,4 - 4,19.

6. Communication, Responden menyatakan setuju terhadap aspek communication, berupa komunikasi tenaga penyuluh dalam memberikan penyuluhan terhadap responden sudah baik dengan nilai 553 atau rata-rata sebesar 3,80 sehingga termasuk katergori baik karena berada diantara skor 3,4 - 4,19.

7. Credibility, Responden menyatakan setuju terhadap aspek credibility, berupa diskusi terbuka yang dilakukan oleh tenaga penyuluh terhadap responden sudah baik dengan nilai 592 atau rata-rata sebesar 4,23 sehingga termasuk katergori sangat baik karena berada diantara skor $4,20-5,00$.

8. Security, Responden menyatakan setuju terhadap aspek security, berupa terbentuknya suasana aman, nyaman tanpa karagu-raguan dalam melaksa nakan penyuluhan yang dilakukan oleh tenaga penyuluh terhadap responden sudah baik dengan nilai 546 atau rata-rata sebesar 3,90 sehingga termasuk katergori baik karena berada diantara skor 3,4 4,19 .

9. Knowing the understanding, Sebagian besar responden menyatakan setuju terhadap aspek knowing the understanding, berupa terpenuhinya kriteria tenaga penyuluh dalam memahami materi yang disampaikan dalam penyuluhan terhadap responden sudah baik dengan nilai 553 atau rata-rata sebesar 3,95 sehingga termasuk katergori baik karena berada diantara skor 3,4-4,19.

10. Customer tangible, Sebagian besar responden menyatakan setuju terhadap aspek customer tangible, berupa penyuluhan telah menggunakan sarana alat peraga atau gambar yang dapat memperjelas materi dengan total skor 569 atau rata-rata sebesar 4,06 sehingga termasuk katergori baik karena berada diantara skor 3,4 - 4,19.

Uji beda persepsi berdasarkan karakteristik responden menggunakan uji t (dua faktor pembeda) dan uji F (lebih dari dua faktor). 
Hasil Uji Perbedaan Rata-rata Persepsi Responden (t-test)

\begin{tabular}{|c|c|c|c|c|c|}
\hline \multicolumn{2}{|l|}{ Atribut } & Rata-rata & t hitung & t tabel & Keterangan \\
\hline \multirow[t]{2}{*}{ Jenis Kelamin } & Laki-laki & 39,333 & \multirow{2}{*}{$-0,183$} & \multirow{2}{*}{1,980} & \multirow{2}{*}{$\begin{array}{l}\text { Tidak ada perbedaan } \\
\text { secara signifikan }\end{array}$} \\
\hline & Perempuan & 39,672 & & & \\
\hline \multirow{2}{*}{ Asal Sekolah } & SMK & 39,323 & \multirow{2}{*}{$-0,682$} & \multirow{2}{*}{1,980} & \multirow{2}{*}{$\begin{array}{l}\text { Tidak ada Perbedaan } \\
\text { secara signifikan }\end{array}$} \\
\hline & SMA & 39,762 & & & \\
\hline
\end{tabular}

Uji t, perbedaan persepsi responden berdasarkan jenis kelamin dengan signifikansi alpha $5 \%$ dan derajat kebebasan $\mathrm{df}(\mathrm{n}-\mathrm{k}) \mathbf{1 4 0 - 2 = 1 3 8}$, diperoleh nilai t table 1,980 dan nilai t hitung $-0,183$ dengan demikian $t$ hitung berada di posisi: $-\mathrm{t}$ table $\leq \mathrm{t}$ hitung $<\mathrm{t}$ table atau $-1,980 \leq 0,183<1,980$, berarti tidak ada perbedaan persepsi responden terhadap penyuluhan materi kesehatan reproduksi remaja berdasarkan jenis kelamin.

Uji t, Perbedaan Pesepsi Responden Berdasarkan Asal Sekolah dengan signifikansi alpha $5 \%$ dan derajat kebebasan $\mathrm{df}(\mathrm{n}-\mathrm{k}) \mathbf{1 4 0 - 2 = 1 3 8}$, diperoleh nilai t tabel 1,98, nilai t hitung -0,682 dengan demikian $t$ hitung berada di posisi: $-\mathrm{t}$ table $\leq \mathrm{t}$ hitung $<\mathrm{t}$ tabel atau $-1,98 \leq-0,682<1,98$, berarti tidak ada perbedaan persepsi responden terhadap penyuluhan materi kesehatan reproduksi remaja berdasarkan asal sekolah.

Uji F (Fisher test) digunakan untuk menentukan apakah tiga kelompok sampel atau lebih memiliki rata-rata yang berbeda. Masingmasing grup terdiri lebih dari dua pilihan. Grup yang berbeda dalam penelitian ini adalah asal daerah, usia, pendidikan orang tua dan kekerjaan orang tua. Perbedaan Persepsi Responden Berdasarkan Asal Daerah, Uji F dengan signifikansi alpha $5 \%$ uji satu sisi serta dengan derajat kebebasan df $(\mathrm{n}-\mathrm{k} ; \mathrm{k}-1)=140-3 ; 3$, diperoleh $\mathrm{F}$ table 3,o6.dan $\mathrm{F}$ hitung 0,468. Karena F hitung 0,468 < F table 3,06, berarti tidak ada perbedaan persepsi responden terhadap penyuluhan materi kesehatan reproduksi remaja berdasarkan asal daerah.

Perbedaan Persepsi Responden Berdasarkan Usia, Uji F dengan signifikansi alpha $5 \%$ uji satu sisi serta dengan derajat kebebasan df(n-k;k-1) = 140-3; 3-2, diperoleh F table 3,06 dan F hitung o,o6o. Karena F hitung o,o6o $<\mathrm{F}$ table 3,06, berarti tidak ada perbedaan persepsi responden terhadap penyuluhan materi kesehatan reproduksi remaja berdasarkan usia.

Perbedaan Persepsi Responden Berdasarkan Pendidikan Orang Tua, Uji $\mathrm{F}$ dengan signifikansi alpha $5 \%$ uji satu sisi serta dengan derajat kebebasan $\mathrm{df}(\mathrm{n}-\mathrm{k} ; \mathrm{k}-1)=140-4 ;$ 4-1, diperoleh $\mathrm{F}$ table 2,67 dan F hitung o,894 F hitung $0,894<\mathrm{F}$ table 2,67 , berarti tidak ada perbedaan persepsi responden terhadap penyuluhan materi kesehatan reproduksi remaja berdasarkan pendidikan orang tua. 
Ringkasan Hasil Uji Perbedaan Rata-Rata Persepsi Responden (F test)

\begin{tabular}{|c|c|c|c|c|c|}
\hline \multicolumn{2}{|c|}{$\begin{array}{ll}\text { Atribut } \\
\end{array}$} & Rata- & F hitung & F tabel & Keterangan \\
\hline \multirow{3}{*}{ Asal Daerah } & $\begin{array}{l}\text { Dalam Kecamtan } \\
\text { Wirobrajan }\end{array}$ & 39,4416 & \multirow{3}{*}{0,468} & \multirow{3}{*}{3,06} & \multirow{3}{*}{$\begin{array}{l}\text { Tidak ada } \\
\text { perbedaan secara } \\
\text { signifikan }\end{array}$} \\
\hline & $\begin{array}{l}\text { Luar Kecamatan } \\
\text { Wirobrajan }\end{array}$ & 40,0244 & & & \\
\hline & Luar Kota Yogyakarta & 39,7727 & & & \\
\hline \multirow{3}{*}{ Usia } & $\leq 17$ tahun & 40,0000 & \multirow{3}{*}{0,060} & \multirow{3}{*}{3,06} & \multirow{3}{*}{$\begin{array}{l}\text { Tidak ada } \\
\text { perbedaan secara } \\
\text { signifikan }\end{array}$} \\
\hline & $18-20$ thn & 39,6371 & & & \\
\hline & $\geq 20$ tahun & 39,6667 & & & \\
\hline \multirow{4}{*}{$\begin{array}{l}\text { Pendidikan } \\
\text { Orang tua }\end{array}$} & SD & 39,6250 & \multirow{4}{*}{0,894} & \multirow{4}{*}{2,67} & \multirow{4}{*}{$\begin{array}{l}\text { Tidak ada } \\
\text { perbedaan secara } \\
\text { signifikan }\end{array}$} \\
\hline & SMP & 40,0000 & & & \\
\hline & SLTA & 38,9091 & & & \\
\hline & PT & 39,8974 & & & \\
\hline \multirow{5}{*}{$\begin{array}{l}\text { Pekerjaan } \\
\text { Orang tua }\end{array}$} & Petani & 38,5174 & \multirow{5}{*}{0,335} & \multirow{5}{*}{2,43} & \multirow{5}{*}{$\begin{array}{l}\text { Tidak ada } \\
\text { perbedaan secara } \\
\text { signifikan }\end{array}$} \\
\hline & Swasta & 39,5294 & & & \\
\hline & PNS & 39,7931 & & & \\
\hline & TNI/POLRI & 40,0000 & & & \\
\hline & Wiraswasta & 39,4375 & & & \\
\hline
\end{tabular}

Perbedaan Persepsi Responden Berdasarkan Pekerjaan Orang Tua, Uji F dengan signifikansi alpha $5 \%$ uji satu sisi serta dengan derajat kebebasan df(n-k;k-1) = 140-3; 5-1, diperoleh F table 2,43 dan F hitung 0,335. Karena F hitung $0,335<\mathrm{F}$ table 2,43 , berarti tidak ada perbedaan persepsi responden terhadap penyuluhan materi kesehatan reproduksi remaja berdasarkan pekerjaan orang tua.

Hasil penelitian menunjukan bahwa karakteristik responden dengan jenis kelamin perempuan sebanyak $98 \%$, berdasarkan pendidikan orang tua $56 \%$ pendidikan perguruan tinggi, berdasarkan usia $89 \%$ berusia antara 18 sampai dengan 20 tahun, berdasarkan asal sekolah $85 \%$ berasal dari SMA, berdasarkan daerah asal 55\% berasal dari Kecamatan Wirobrajan Yogyakarta, serta jika berdasarkan pekerjaan orang tua $41 \%$ sebagai PNS. Hasil penelitian ini juga menunjukan bahwa sebagian besar responden lebih menyukai metode langsung 66\%, sedang yang menyukai metode tidak langsung sebesar $34 \%$. Berdasarkan uji beda rata-rata persepsi responden penyuluhan kesehatan reproduksi baik menggunakan uji $\mathrm{t}$ maupun uji $\mathrm{F}$ ternyata tidak ada perbedaan yang signifikan pada masing-masing karakteristik. Perbedaan persepsi responden terhadap penyuluhan kesehatan reproduksi remaja berdasarkan karakteristik jenis kelamin dan asal sekolah dilakukan dengan menggunakan uji t. Hasil uji t menunjukan 
bahwa tidak ada perbedaan persepsi terhadap penyuluhan materi kesehatan reproduksi remaja berdasarkan jenis kelamin, artinya penyuluhan yang diberikan tidak membedakan peserta dengan jenis kelamin, sehingga persepsi responden tersebut sama baik jenis kelamin perempuan atau lakilaki. Jika dilihat dari asal sekolah hasil uji t menunjukan bahwa tidak ada perbedaan persepsi baik dari responden yang berasal dari sekolah SMA atau responden yang berasal dari SMK. Berdasarkan uji $\mathrm{F}$ menunjukan bahwa tidak ada perbedaan persepsi responden terhadap materi penyuluhan kesehatan reproduksi remaja berdaarkan daerah asal, usia, pendidikan orang tua dan pekerjaan orang tua. Secara keseluruhan hasil penelitian ini dapat disimpulkan bahwa penyuluhan kesehatan reproduksi remaja di Kecamatan Wirobrajan Yogyakarta dapat diterima oleh responden dibuktikan dengan hasil bahwa tidak terdapat perbedaan persepsi berdasarkan atribut-atribut yang dimiliki oleh responden.

\section{KESIMPULAN}

Kesimpulan dalam penelitian ini adalah untuk mengetahui persepsi remaja terhadap penyuluhan Kesehatan Reproduksi Remaja.

1. Berdasarkan jenis kelamin sebanyak 137 atau $98 \%$ remaja berjenis kelamin wanita.

2. Berdasarkan dari umur sebanyak 124 atau $89 \%$ berusia antara 18 tahun sampai dengan 20 tahun

3. Berdasarkan daerah asal sebanyak 77 remaja atau sebesar $55 \%$ berasal dari Kecamatan Wirobrajan Yogyakarta

4. Berdasarkan dari asal sekolah sebanyak 119 remaja atau $85 \%$ berasal dari sekolah SMA

5. Berdasarkan pendidikan orang tua sebagian besar berpendidikan Perguruan Tinggi yaitu sebanyak78 remaja atau sebesar $56 \%$

6. Sebagian besar pekerjaan orang tua sebagai PNS yaitu sebanyak 58 remaja atau sebesar $41 \%$

Penilaian responden terhadap atribut penelitian yang terdiri dari Responsiveness, Reliability, Competence, Acces, courtesy, comunicatio, security, knowing the Undestanding, Customer Tangible semua responden berpersepsi baik, sedangkan atribut credibility responden berpersepsi sangat baik.

VIII. DAFTAR PUSTAKA

Basu Swastha DH dan T. Hani Handoko. 200o. Manajemen Pemasaran Perilaku Konsumen. Yogyakarta: BPFE. 
BKKBN. 200o. Kesehatan Reproduksi Remaja (KRR), Modal Pelatihan Belajar Madiri Bagi Widyaiswara. Jakarta: BKKBN.

Ciptono, Fandi. 2001. Manajemen Jasa. Yogyakarta: Andi Offset.

Jarwanto dan Pangestu Subagyo. 1997. Statistik Induktif, Edisi 4. Yogyakarta: BPFE.

Sugiyono. 1999. Metode Penelitian Bisnis. Bandung: C.V. Alfabeta. 